\title{
ANCIENT CITY CONNECTED WITH THE NAME OF THE WELL "KHEYVAQ"
}

\author{
Gavkhar Durdiyeva ${ }^{*}$, Adilbek Zargarov ${ }^{1}$, Ergashbek Salayev ${ }^{1}$ \\ ${ }^{1}$ Khorezm Mamun Academy, regional branch of Academy of Sciences of the Republic of Uzbekistan, Markaz \\ №1, Khiva city, Republic of Uzbekistan \\ *E-mail of corresponding author: gavhar61@mail.ru.
}

Abstract: In this article analytical information and facts about ancient monuments that play a main role in the 2500 years history of Khiva, monuments of Museum reserve of Ichan Kala which locate on 26 hectares, The well Kheyvaq that is considered cultural and precious heritage of Khiva, The Gates of Ichan Kala and the walls in the length of 2600 meters that surround totally 54 ancient monuments, are presented.

Keywords: Ichan Kala, Deshan Kala, architectural monument, kheyvaq, well, gates.

\begin{tabular}{c}
\hline $\begin{array}{c}\text { Received: } 6.5 .2020 . / \text { Accepted: 02.06.2020. } \\
\text { Published online: } 10.07 .2020 .\end{array}$ \\
\hline $\begin{array}{c}\text { Professional paper } \\
\text { https://oi.org/10.37023/ee.7.1.5 }\end{array}$
\end{tabular}

\section{INTRODUCTION}

Today it is one of the main tasks for each native to learn and research information related to Khiva. Because this city has the ancient history in the world civilization like Rome, Egypt and Mesopotamia.

Taking into account the special role of Khiva in the development of world culture, the $28^{\text {th }}$ session of the UNESCO General Conference held in Paris in October-November 1995 adopted a resolution to celebrate the $2500^{\text {th }}$ anniversary of Khiva worldwide. On October 20, 1997, the 2500-year anniversary of Khiva was widely celebrated (Khiva 1997). Ichan-Kala, considered as a miracle of Khiva, was recognized as the only reserve in Central Asia in 1967, and in December 1990 was included in UNESCO's list of world culture and heritage and the city was given the high status of "Khiva - an open-air museum city!" (Figure 1)

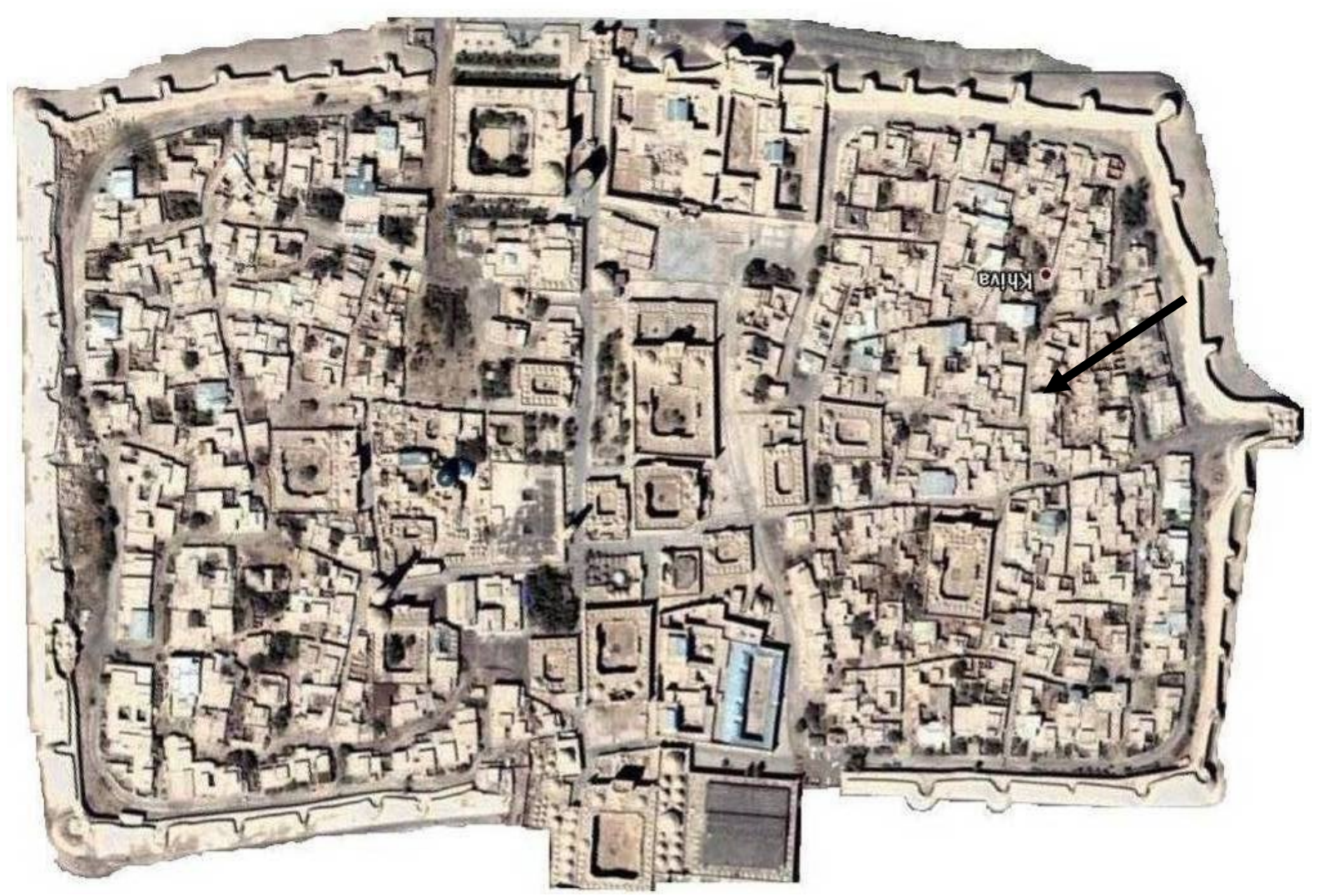

Figure 1. An aerial photo of the Museum reserve of Ichan Kala where the well "Kheyvaq" is located This figure was taken by google map. 
As the First President of Uzbekistan, Islam Karimov said, "Khiva is the pearl of our beautiful country, a symbol of the art and creativity of our people, a miracle that embodies the eternity of our cultural and spiritual traditions".

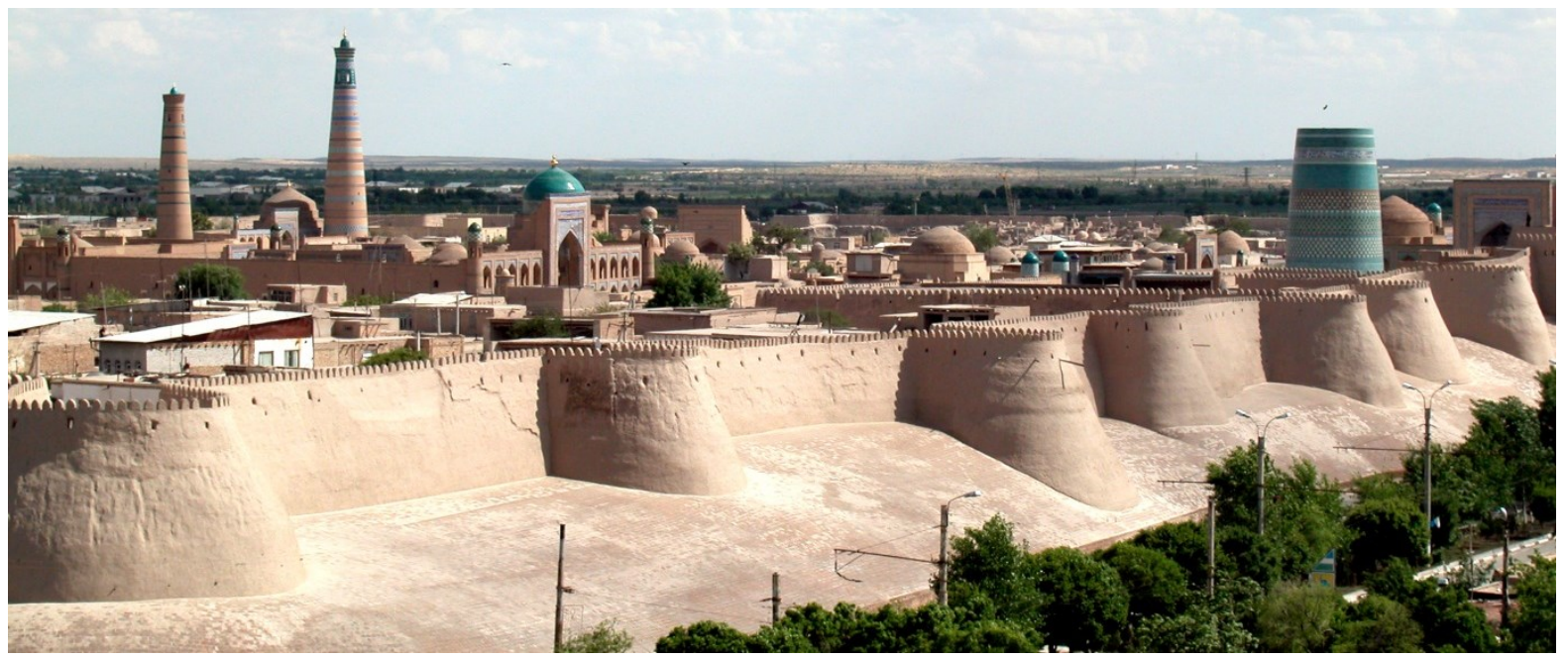

Figure 2. The aerial photo of north-western part of the walls of Ichan Kala. This photo was taken by author of this article.

\section{THE MUD WALLS OF ICHAN KALA}

The main elements of the ancient antique cities are the castle walls. Its main purpose is to protect the city from its external enemies. The nearly 3,000-year-old city of Khiva's Ichan Kala is a pinnacle of Central Asian fortresses with its elegance, high defense, and the rising culture (Khiva 1997).

The fortress has four gates, to the south is "Tash Darvaza", to the north is a "Bogcha Darvaza", to the east is a "Polvon Darvaza", and to the west is the "Ota Darvaza". During the Khiva khanate, there were several cemeteries around the fortress (Gulamov 1941). According to the old men, these graves were set up so that enemy soldiers, who understood the Muslim pillars in the invasion wars, could not pass through the tombs, that is, to attack the fortress from the place where the graves were located (Figure 3).

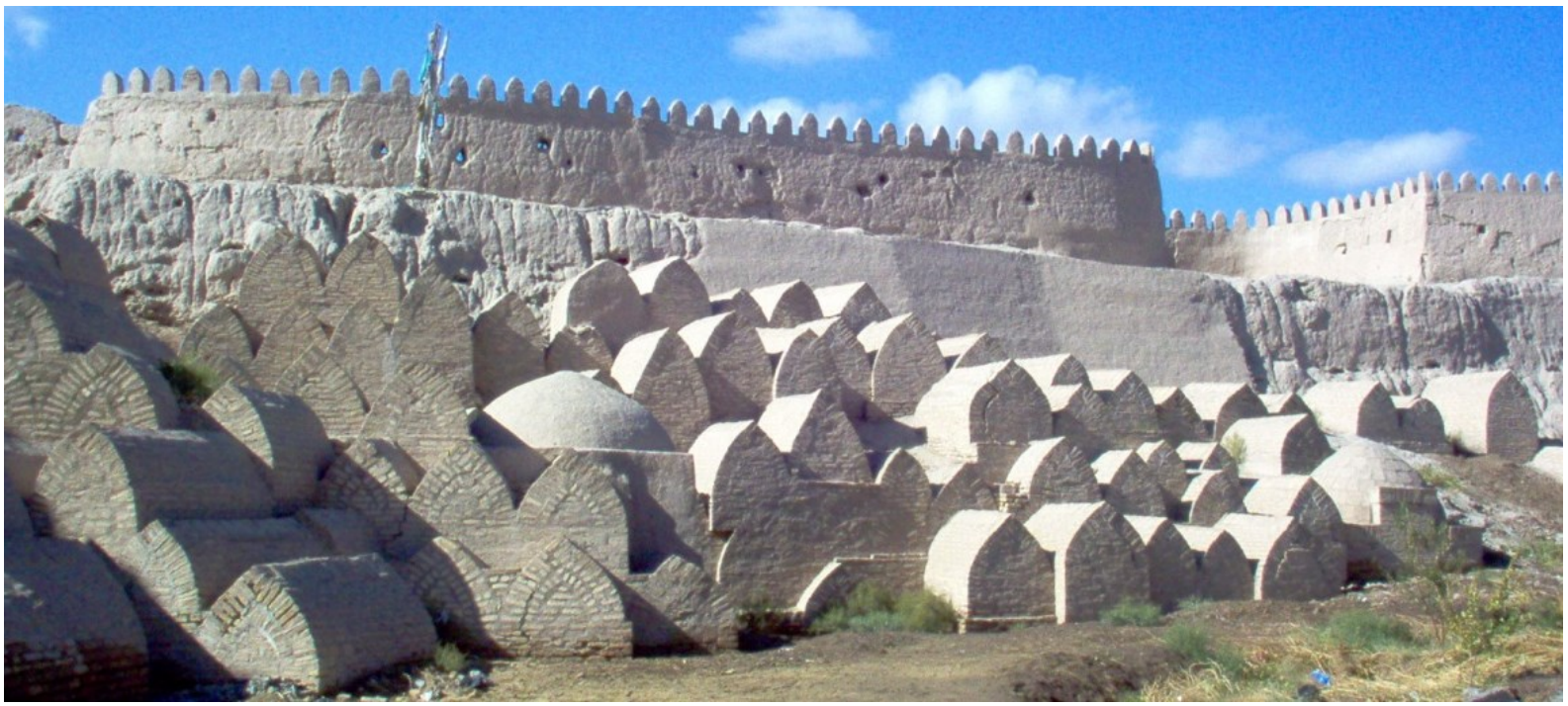

Figure 3. The cemetery around the fortress wall near Tash Darvaza of the Ichan Kala Museum-Reserve. Southern part of Ichan Kala. This photo was taken by author of this article.

By the beginning of the $20^{\text {th }}$ century, Ichan-Kala had become an inner city with a whole complex of architectural composition. The wall of the Deshan Kala was formed around the Ichan Kala. The town was inhabited by the poor, artisans, and small merchants.

In some parts of the fortress where thickness of the walls is up to 8-10 meters, three rooms were created alongside the length of the walls. In the Figure $\mathbf{4 b}$ an entrance to inner room, just like we said above, is shown in the north part of the fortress. On the occasion of the of 2500th anniversary of Khiva an arheological research was undertaken and large bricks related to the antique period were found in the rooms. 


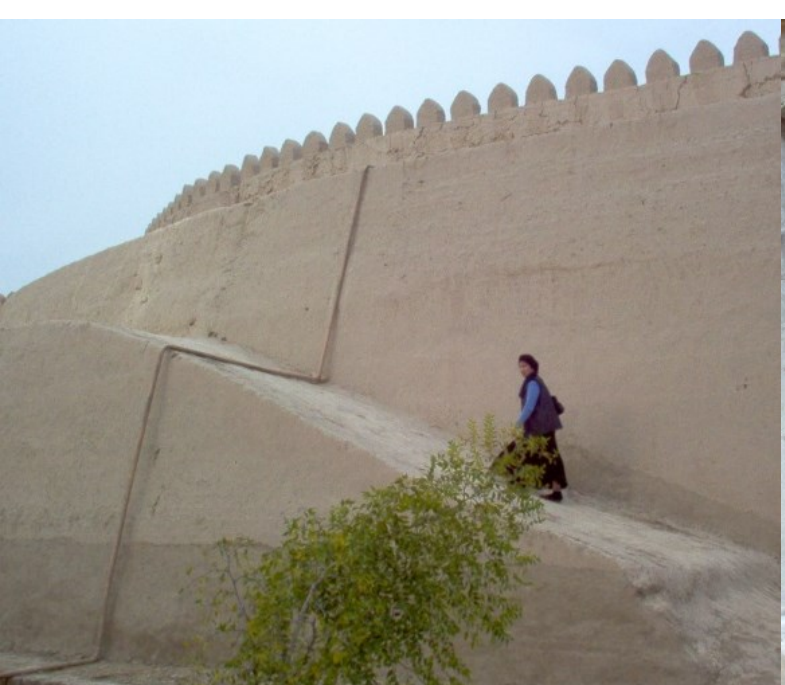

a)

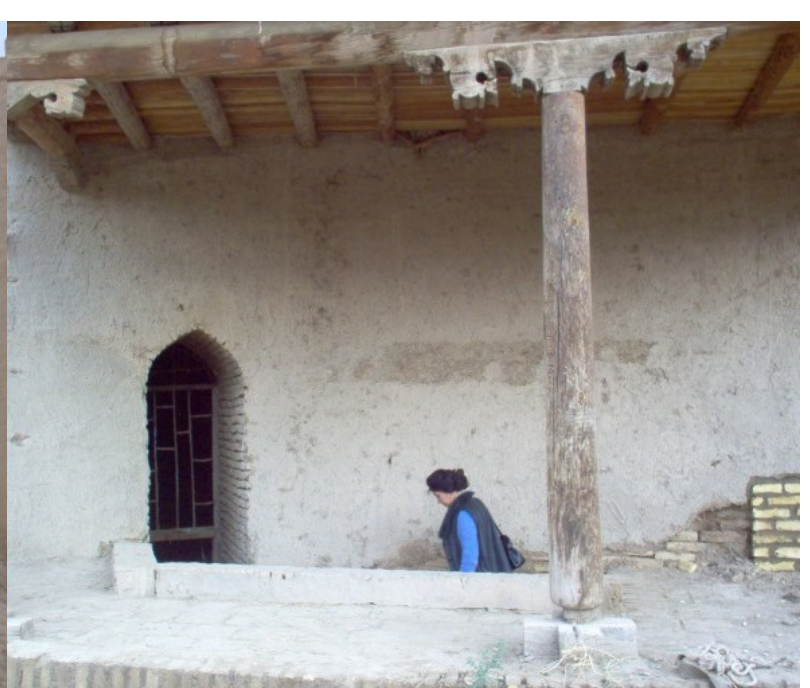

b)

Figure 4. The upstairs part of the fence, in ancient times, provided food and weapons to the warriors standing in chariots (a), and the room between the wall to the north of the wall (b). In these photos the northern part of the walls of Ichan Kala was presented.These photos were taken by author of this article.

The interesting story of the Khiva historian Khudayberdi bin Awaz Muhammad is full of the ancient history of Khiva. He writes in his strange language: "Raml is another city in Khorezm. It was founded by Sam bin Nuh, now called kheyvaq. The town's former name is Raml, which means sandy. One day, Sam ibn Nuh was sleeping on this bed, and he dreamed that he was in the middle of three hundred lighted torches. He woke up happily. Then he wanted to leave a memory from himself and hesmoothed here and built a city. Another time he came here, he surrounded the place with walls and dug a well on the west side. In short, kheyvaq was said to had been destroyed and rebuilt many times".

\section{THE STRUCTURE OF THE WELL KHEYVAQ}

The bottom of the well is "hammer", the brick bottom is cylindrical, the middle part is rectangular, and the upper part is eight-sided. It is natural for every visitor to Khiva to ask, "Was there a well or had a castle been built before?" But I would say - wells first appeared.

The kheyvaq well is located in the northeastern part of Ichan-Kala near the Bogcha Darvaza, in the courtyard of a man known as the Madirim Crook (Figure 6).
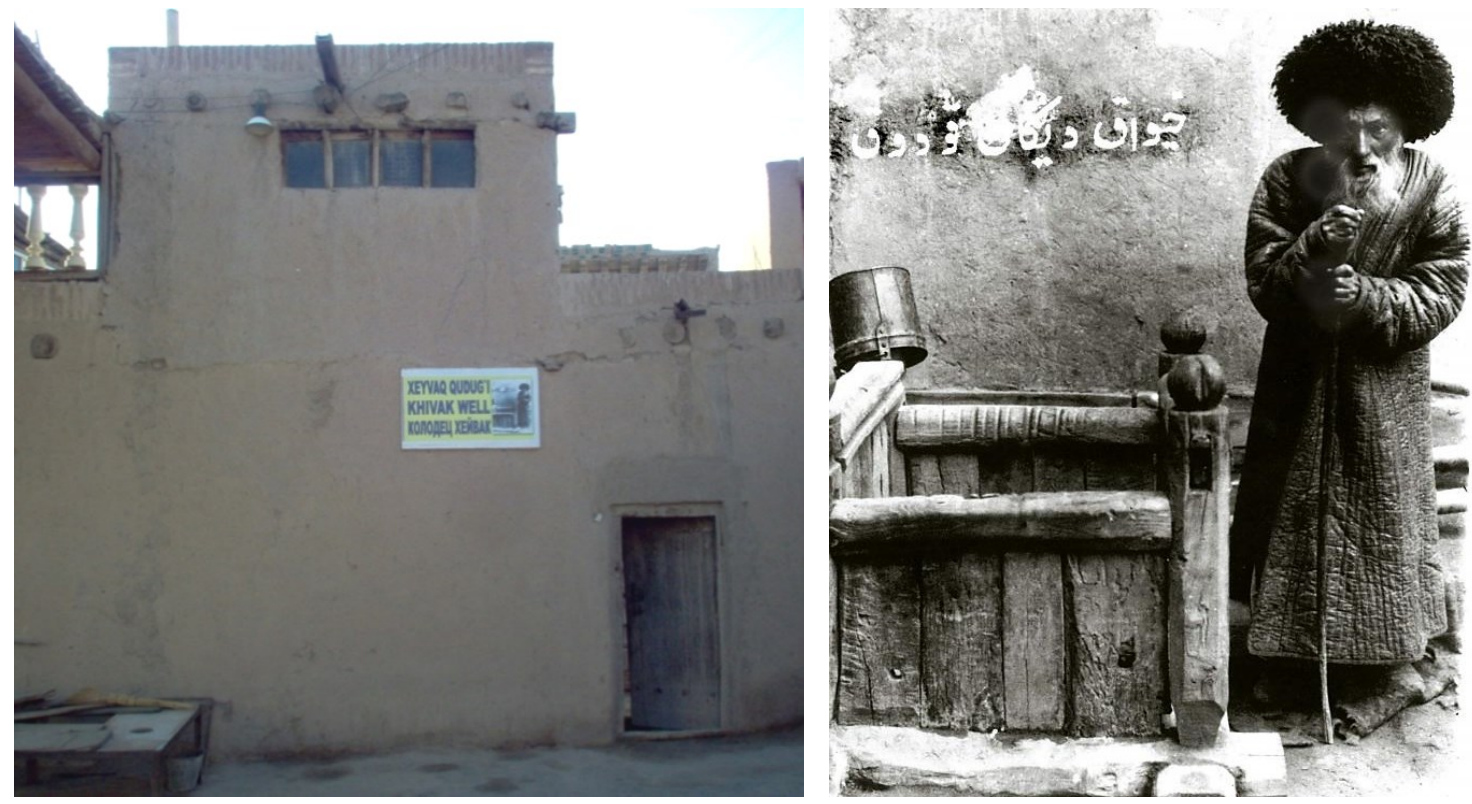

Figure 6. Facade section of the ancient courtyard, where the "Kheyvaq" well is located and the old man standing next to the well. The photo on the left was taken by the author, and the one on the right was taken from the Fund of Museum-reserve of Ichan Kala. 
Every story has truth, first of all, because the thing needed for life is water, people gathered around the well and started to live together, then a city was built gradually. Later the city was surrounded by walls because of the changes of sovereigns and wars.

The bottom of the Kheyvaq well is spun out of grooves. In this case, ancient craftsmen, who know how to tolerate moisture-resistant and groundwater intake as a rigid structure tree, can dig a well from 1.0 to 2.0 meters in the form of a cylinder (Figure 7).

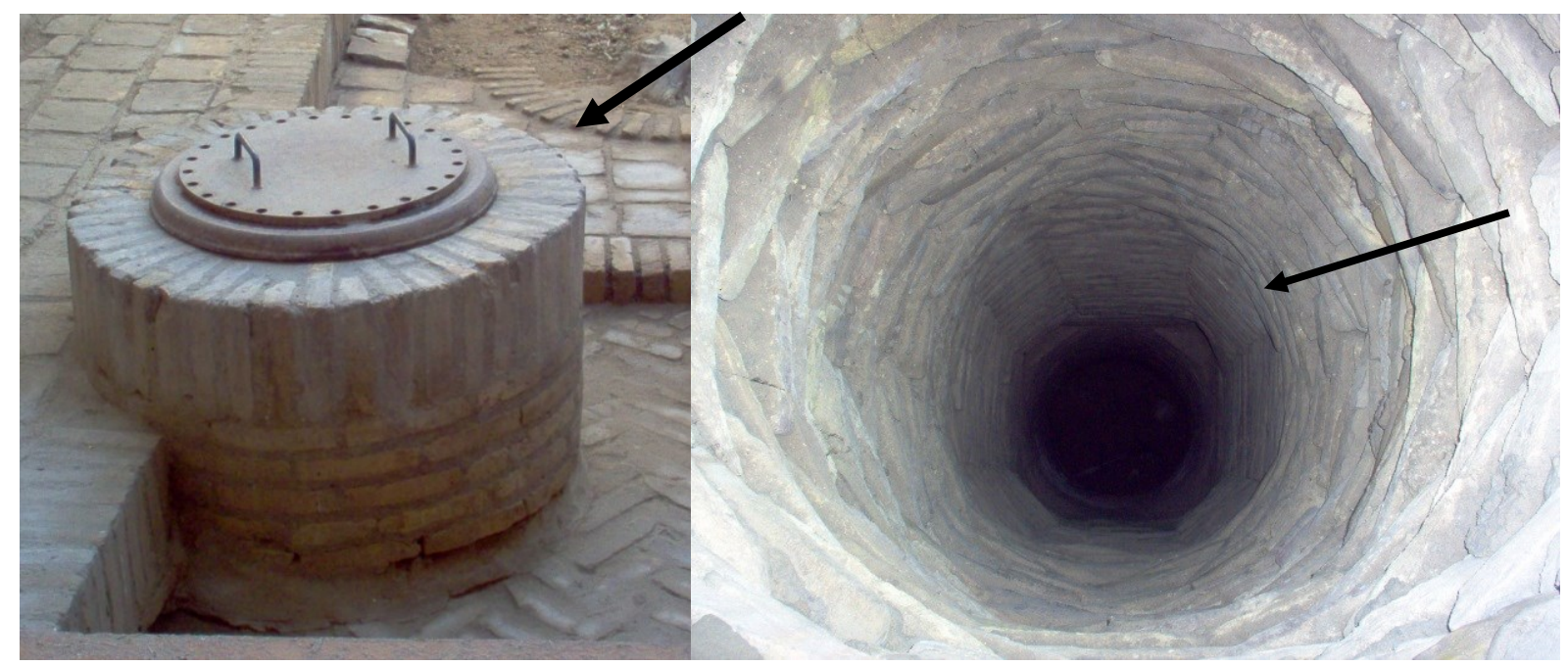

Figure 7. These are the current views of the well. The top part of the well was later rebuilt with burnt bricks and the inner part was remained as it was before. Photos taken by author.

According to the book "Khorezm", written by R. Kalandarov and others: "The stone was laid in the bottom of the Khiva well in three layers. The bottom part is cylindrical, then rectangular and the upper part is octagonal. The former was covered with a dome

In 2007, we researched the history and technical condition of the historic architectural monument of the kheyvaq well [4]. At that time, there was no water at a depth of 7.0 meters. The diameter of the well is $1.0 \mathrm{~m}$. The bottom of the well, up to $1 \mathrm{~m}$, is made of"rosy" - "squat" and the upper part is made of stones, with a rectangular Muslim brick, of which dimension is " $25.0 \times 25.0 \times 5 \mathrm{~cm}$, near the ground level and the upper part of the well.

The Ichan-Kala elders say that the eye of the well, which collects groundwater was covered with sand and soil afterwards. A man named "Sadullahoqsoqol" who once lived in the area (in the 1950s), wanted to dig the well, but the sand dug into the ground. Because of this, the well is not drilled and there is no water in the well as groundwater levels have been decreasing over the last two years.

\section{CONCLUSION}

In conclusion Khiva saved its ancient beauty and rich in wonderful history and a beautiful city just like the ones described in the Eastern legends. Ichan Kala and Deshan Kala are unique collections of architectural monuments of XIV-XX centuries in Central Asia. Natives appreciate and take care of them. They have been proud of those places, Because there are many historical and architectural monuments and old households. The constructors, who built the ancient monuments in Khiva, knew mathematics and geodesics as well as the astronomy. And they were the best at art of architecture and succeed in urbanization too.

\section{REFERENCES}

"Khiva - a city of thousand domes" colorful album. (1997) "Sharq" Main editorship of concern of publishing house Tashkent

Gulamov Y (1941) Monuments of Khiva city//Labours UzFAN. Number 1. History, archeology. Edition 3. Tashkent, 1941. P.24

Mankovskaya L, Bulatova V (1978) Monuments of architecture of Khorezm, Tashkent, pp 119

A scientific-technic report on the theme: "Controlling the monitoring of the architectural monuments of Ichan Kala in Khiva city and creating their data base". Scientific-technic state system of the Republic of Uzbekistan, Grant ID-4-3, Project of Innovation. Khiva-2017 